\title{
A Note On Child Neglect In American Victorianism: Henry James' "The Pupil"
}

\section{Amerikan Viktoryanizminde Çocuk İhmali Üzerine Bir Belge: Henry James'in "The Pupil" Adlı Öyküsü}

\author{
F. Gül KOÇSOY ${ }^{1}$ \\ Fırat Üniversitesi
}

\begin{abstract}
Özet
Bu çalışmada, Henry James'in "The Pupil" (1891) adlı öyküsünde "ihmal edilmiş çocuk" konusu incelenmektedir. Morgan, 19. yüzyılın son çeyreğindeki Amerikan kültürel bilincini yansıtan Viktoryan değerlerine sıkıca bağlı olan ilkesiz ebeveynlerin ihmal edilmiş çocuğudur. Harika bir çocuk olmasına rağmen, aile onu sevmez; çünkü onlara bayağılıklarını anımsatmaktadır. Onu fiziksel ve duygusal olarak inmal eder, yük olarak görürler. Özel öğretmen, çocuğu ailenin yozlaşmışlığından uzak tutmağa çalışsa da hastalığını ihmal ederek ve en çok ihtiyacı olduğu bir zamanda onu terk ederek ölümünde pay sahibi olur.

Yorumcu olarak James, çalışmayıp evde eğitim alan çocukların durumuna dikkat çeker. Bu kültürün çocuklara karşı genel tutumunu eleştirir. Bu, rahatsız edici toplumsal bir gerçektir ve James bu maddeci kültürün çocuklara inmalci ebeveynlik yoluyla nasıl zulmettiğini gösterir.
\end{abstract}

Anahtar Kelimeler: "ihmal edilmiş çocuk", ebeveynlik, Viktoryan kültürü, Henry James, "The Pupil".

\begin{abstract}
In this study, the theme of "neglected child" in Henry James' "The Pupil" (1891) is explored. Morgan is a neglected child with unscrupulous parents who hold strictly on the Victorian values which reflect American cultural consciousness in the last decades of 19th century. Although he is a brilliant boy, the family does not love him; because he reminds them of their vulgarity. They neglect him physically and emotionally, seeing him as a burden. Although his tutor tries to keep the boy from the family's corruption, he contributes to his death; he neglects his illness and deserts him when he is most needy.

As an interpreter, James draws attention to the situation of children that are not working but being tutored at home. He criticizes this culture's general attitude towards children. It
\end{abstract}

\footnotetext{
"This article is the extended version of the paper named "A Neglected Child in Victorian Family: Henry James' 'The Pupil' ", which was presented at the $9^{\text {th }}$ International IDEA Conference: "Studies in English". 15-17 April 2015, Department of Western Languages and Literatures, Inonu University-Malatya.

${ }^{1}$ Assist. Prof. Dr., University, Faculty of Humanities and Social Sciences, Dep. of Western Languages and Literatures., nurgul25@yahoo.com.
} 
is a disturbing social reality and he shows how that materialistic culture victimizes children in terms of neglectful parenting.

Key Words: "neglected child", parenting, Victorian culture, Henry James, "The Pupil"

\section{Introduction}

Although child neglect is a prevalent type of maltreatment that may lead even to life-threat in the short and long-run, it is often discarded or underestimated. Negative impacts of it on children's cognitive, socio-emotional and behavioral development can lead to psychological and physical problems in the future life of children. Its results are important for the child and the society. As a prescient critic of his time, Henry James (1843-1916) is aware of this fact. He is best known for his international themes, but if we think about What Maisie Knew (1897), The Turn of the Screw (1898), "The Pupil" (1891), or some others, we see him also at his best in writing on the relationships between family and children.

James shows the discrepancy between what his Victorian contemporaries idealize about children and what their reality is. He witnesses Victorians' childrearing practices as neglectful and demonstrates the deficiencies of Victorian culture in this context. He talks about negative effects of unsafe, unstable and non-nurturing family conditions. He attacks the $19^{\text {th }}$ century ideals of childhood that depicted children as happy, smiling, innocent and unaware of the real world. He subverts this 'pure child' myth and demonstrates a type of realistic child:

James's child characters do not spend their time in the typical settings of nineteenth-century literary children, opening Christmas presents, adventuring, playing, or learning with other children, but rather in the social world of adults. They are not at all interested in conventionally childish things. They are not even particularly childish themselves. Instead, they resemble James's adult characters in their passion for intense observation. (Michals: 2011,237)

"The Pupil" addresses eleven-year-old Morgan Moreen who is the youngest child of a wandering American family in Europe. He seems strange in such a family, because he has an adult understanding of his family's preoccupation with money and status. In the microcosm of this family, James exhibits the illusionary points of view about familial relationships and family structure within that culture.

Transmission of culture and moral codes was one of the most emphasized tenets of American Victorian values, and apparently it was dependant on children, who were regarded as public good and warrant of future. Giving home education to children was one of the showy aspects of this culture. It created not only the image that they cherish their children and culture but also they are 
rich. Imitating middle-class mannerisms and virtues like domesticity, paying value for science and education, and emphasis on morality were the main components of this world-view.

A time of dualities, Victorian era not only in England but also in the United States sheltered contrasts. From the Puritans, American Victorians inherited the idea of a strong bond among state, family and individual in that they had to be disciplined. The most significant feature of American Victorianism (1837-1901) was ostentation, materialism and hypocrisy. Genteel Tradition contributed to this movement in terms of its stress on high culture. A lifestyle based on manners and social graces was preferred among the middle-class people, who in general had artificial attitudes in social milieu to show their respectability and exposed their natural behaviors and ideas in the private places. "They wanted to make the age-old concept of gentility an achieved, rather than an ascribed, status; they hoped to accomplish this through a massive educational and propaganda effort." (Howe: 1975: 516) To reach a significant place in society - for this was important for them - improvement, education and emulation were ideals to seem gentile. They did not adopt gentility for its own sake but to enjoy its benefactions and they expected education to aid them get a stable and desirable position. Education was also important in instilling the proper values in their children, cultivating efficient citizenship and required talents for respectable personalities, but in practice, it was defined as elitism. Victorian psyche might be described as the amalgamation of social theories and aesthetics, but this intellectual culture disregards the consequences of child neglect. On the other hand, their verbal emphasis on duty, virtue and morality becomes hypocritical when they find no place in real life. Financial, social and familial life is not based on clear terms; they talk about the importance of science and education but their behaviors prove the reverse.

\section{Discussion}

In this context, James presents the two sides of the family: one, the family's public appearance in the social sphere, and the domestic one at home. The spheres hold two conflicting value systems. The family members are typical middle-class Victorians; they lack cultural background to take place in the social activities of upper-class European families but are ambitious to ascend the social ladder and they love showing-off. They lead a hand-to-mouth life, living mostly on macaroni and coffee, but for their public appearance and parties, they spend much on clothes. They cannot support themselves legitimately, so they lie, cheat, and toady people easily for they are polyglot. Their impecuniousness is understandable but their irresponsibility and low morality is inexcusable. They mostly use excuses and lies to justify their life-style. For instance, for sudden departures from Nice to Switzerland, and then to Florence or Paris, where they stay at third-rate neighborhoods or hotels, their excuse is to find a better place. Most importantly, they disregard the fact that they exhibit ethically false examples for a child when he is in the character formation period. Rather than authoritarian parenting, the parents exhibit verbal hostility to Morgan, because 
he is an intellectual, critical and talkative boy; they dislike him especially for this. "They even praised his beauty, which was small, and were as afraid of him as if they felt him of finer clay." (James:2014) So, their leaving Morgan to tutors without wondering comes not only from neglectful parenting, but also from dislike because he is ill and prudent enough to understand their lowness. Tragedy and plight of a child because of social norms become apparent at this point.

Despite his critical illness, Morgan is not paid necessary care and kindness; he gets insufficient nutrition and hygiene. He is also denied emotional and intellectual support from any member of the family. On the contrary, he is mocked or disregarded by his original and clever thoughts. He is aware that his mother wants to get rid of him. The other members of the family are unconcerned about him, not warning the mother or sharing his thoughts and feelings. Morgan is aware of all the facts about his family in that it has not a financially ordered life, nor has an ordered residence. He also knows their feelings and thoughts about him. The parents are potentially harmful to Morgan due to their lack of parental motivation and care which means failure in support and supervision for his development. One of the tenets of the Victorians is the idea that material and bodily well-being reflects moral goodness and God's countenance. Morgan is out of the sphere of this definition. The girls and an elder-brother are not at all interested in him. Family environment is obviously hostile to him; because according to the members, his illness signifies his moral wickedness. Thus, it is normal for the class-obsessed and atrocious parents to discard him easily and wait for his death doing nothing. He is very well aware of his own condition as an unwanted child that his family does not love him truly and sincerely because he is unhealthy. James here hints that Victorian point of view makes family members remote and indifferent to one another out of material causes. Morgan responds to this attitude assuming cynical manners and speech. He feels coldness and remoteness to his mother and reveals her lies openly in front of people as vengeance. Pemberton, when he first comes to the house, is assured by her that the wage will be satisfactory and regular, but Morgan implies that it is a lie:

"They'll give you anything you like," the boy remarked unexpectedly...We don't mind what anything costs - we live awfully well."

"My darling, you're too quaint!" his mother exclaimed, putting out to caress him a practised but ineffectual hand.... "You pompous little person! We're not extravagant!" Mrs.Moreen gaily protested, making another unsuccessful attempt to draw the boy to her side. "You must know what to expect," she went on to Pemberton.

"The less you expect the better!" her companion interposed. "But we are people of fashion." (James: 2014) 
Like the mother, Mr. Moreen pretends. Having heard about the contemporary child-rearing approaches - secular, rationalist, democratizing, and which prescribe socialization and advancement, he summarizes his ideas of family life:

He further mentioned that he aspired to be intimate with his children, to be their best friend, and that he was always looking out for them. That was what he went off for, to London and other places - to look out; and this vigilance was the theory of life, as well as the real occupation, of the whole family. They all looked out, for they were very frank on the subject of its being necessary." (James:2014)

Mr. Moreen pretends to be a caring father, but in reality he is not interested in his children; he rarely speaks to them. He often disappears to find better possibilities for the family, he says, but this proves futile. He pretends to be noble, but Pemberton finds him shaving in a room. He does not work in a specific place; more accurately, the source of their income is not clear. They all 'look out' though, to attain new possibilities for earning money and showing themselves in the high societies of Europe.

When Pemberton comes to work at the Moreens', he immediately sees that the manners of the family members are affected, studied and unnatural. Their seemingly elegant manners are not internalized. They have problematical casts of mind: class consciousness and material well-being come before parental and familial responsibility. Vulgar and morally unfit, the parents are not well-adjusted for child-rearing. Morgan's elder sisters are also loose to pursue upper-class husbands explicitly: "These young ladies were not at all timid, but it was just the safeguards that made them so candidly free. It was a houseful of Bohemians who wanted tremendously to be Philistines." (James:2014) Apart from these, Morgan is not supervised by the family. In the Victorian atmosphere of domesticity, it is a known reality that servants and teachers might do harm to the children; there is the risk of sexual abuse. In spite of knowing this, Morgan's parents leave everything about him to Pemberton. He is a stranger and Morgan is together with him all day. They have discarded him to an extent to leave them together all the time. Luckily, Pemberton is a good-intentioned person and though an elite educational setting is not possible under such circumstances, he does his best to be helpful and beneficial to his pupil. Morgan forms a friendship with Pemberton with whom he can share many of his interests. Pemberton buys clothes for Morgan, which means that he feels obliged to share the family's expenses.

Mature and prudent enough to accept the conditions, Morgan is ashamed of his family, but more of his parents' cheating the tutors about salary. He feels humiliated towards them. With a deteriorated ethical view, they hold the tutors as family members. They do not feel themselves bound to pay them; moreover, they try to borrow from them. They know well that Pemberton cannot leave tutorship for Morgan, and when Mrs. Moreen implies this, he is shocked: 
...Pemberton could enjoy a moral. The Moreens were adventurers not merely because they didn't pay their debts, because they lived on society, but because their whole view of life, dim and confused and instinctive, like that of clever colour-blind animals, was speculative and rapacious and mean. Oh they were "respectable," and that only made them more immondes. The young man's analysis, while he brooded, put it at last very simply-they were adventurers because they were toadies and snobs. That was the completest account of them-it was the law of their being. Even when this truth became vivid to their ingenious inmate he remained unconscious of how much his mind had been prepared for it by the extraordinary little boy who had now become such a complication in his life. (James:2014)

Since he has shelter and has the "privilege of knowing and living with so amazingly gifted a child..." (James:2014) it will be indecent to expect money, according to the mother. Through a play of logic, she tries to make him feel guilty, even beholden to them. Morgan, with a critical eye, can see their depravity before Pemberton:

"I don't know what they live on, or how they live, or why they live! What have they got and how did they get it? Are they rich, are they poor, or have they a modeste aisance? Why are they always chiveying me about-living one year like ambassadors and the next like paupers? Who are they, any way, and what are they? I've thought of all thatI've thought of a lot of things. They're so beastly worldly. That's what I hate most-oh, I've seen it! All they care about is to make an appearance and to pass for something or other. What the dickens do they want to pass for? What do they, Mr. Pemberton?" (James: 2014)

Here, Mrs. Moreen seems right: Pemberton will not be able to leave the Moreens. The answer to these questions and Morgan's vulnerable heart illness put Pemberton in difficult position. He pities Morgan for he is emotionally battered, or like him very much for he is a very intelligent, hardworking and good boy. The family members are so deteriorated that they are not disturbed whether Morgan is aware of everything or not. It becomes a complex issue for him to leave this wonderful child alone with this family. That is the situation, and the parents benefit from it cunningly. He is not healthy, and can die any time. It is obvious that they 'look out' for any benefit coming through him: for example, giving a false image to the society that they love their son very much and they are rich enough to have a private tutor for him.

In fact, the situation is the reverse. If "[p]hysical neglect refers to harm or endangerment as a result of inadequate nutrition, clothing, hygiene, and supervision..., and emotional neglect includes failure to provide adequate affection and emotional support..." (Kaplan:2000,53-54), then Morgan is neglected greatly. He meets all the elements of the definition, unfortunately. He is not grown up with his physical and psychological needs met: he gets poor 
nutrition and hygiene, and improper clothes because he is deliberately not shown in the public. Concerned about the social positions of her older son and eligible daughters, the mother spends more on their clothes for showoff:

She did nothing that didn't show, neglected him because he escaped notice, and then...discouraged at home his public appearance. Her position was logical enough - those members of her family who did show had to be showy. (James:2014)

Here, James ironically reflects her point of view about him: for he is not seen in public sphere, his old and holey stockings are not important. She does not bring to mind his psychology in shabby clothes.

As a mother, even if Mrs. Moreen is burdened with the duty of managing the house and the family alone - for her husband is irresponsible -, she is unresponsive and unsupportive to her diseased child. Victorian culture burdens women too much within the house, but in this story 'the angel of the house' also exerts effort to economize from the family food; especially for appearances. She cannot find money for Morgan's medical care but spends much money for the public appearance of her family except him. She is mostly interested in 'looking out' for affluent husbands for her two daughters. Here, James underlines the fact that for the sake of social necessities, that culture constrains people from paying attention to the psychological and physical needs of one's family. The mother makes plans to give away Morgan in order to spend her full time on the others. Although she knows that he is ill by heart, she does not avoid talking about critical subjects like adoption when he is near her. Even compared with the Victorian standards and beliefs, he is neglected. He is not taught 'proper values' to socialize and develop himself according to the values. He has no friend and has adverse experiences as a result of living with this family. While poverty can be regarded as a factor for neglect, feelings of hopelessness and helplessness distress Morgan's psychological health more.

Being unhappy and in need of love, Morgan easily becomes dependent on his teacher. Pemberton recognizes the needs for help and feels morally obliged to support him in his own possibilities. They become two friends, enjoying the Louvre, buying used books, and gossiping and joking about the family's follies. Besides these enjoyable moments, Morgan also feels deeply ashamed and humiliated towards Pemberton, because the parents do not pay him. He sees Pemberton as a hero, too. With these feelings, Morgan is hopeful that he takes him away from the family for good. He has false dreams that he goes to Pemberton's college at Oxford and by the help of him does extraordinary things. Here, Pemberton fills him with hope about a mutual future without estimating its probable results.

The last and the most confusing behavior of the mother after four years, comes when she asks Pemberton to assume full responsibility for Morgan. On the other hand, Pemberton participates and shares the family's life-style. He 
becomes resilient and gets used to their follies. Deteriorating value system of the Victorians also captures Pemberton's sympathy for Morgan. He determines to take the boy away altruistically, but later gives up. He is incapable of determining things, and when he implies financial excuses, he proves himself not courageous to take the child. He is a passive man; even if he pities him and has affection for him, it is Morgan who proposes to leave the family. Pemberton is too improvident to fill him with false dreams. Being not enthusiastic, Pemberton "has become spiritually a Moreen." (Canavan:1973,259) and he is aware of his deterioration:

He accused himself, at bottom and not unveraciously, of a fantastic, a demoralized sympathy with her. If misery made strange bedfellows it also made strange sympathies. It was moreover a part of the abasement of living with such people that one had to make vulgar retorts, quite out of one's own tradition of good manners. (James: 2014)

Pemberton criticizes himself honestly, but attributes the cause of his decision to financial restraints. It is the easy defense-mechanism and he finds himself right to break his promise. He could take Morgan at least for a while, not for good. With pitying the family when he must not and his inability to take sides, his consciousness of ethics proves to be shaken.

When financial collapse comes officially and publicly for the family, in the end, it becomes apparent that they are charlatans and even their clothes are confiscated. They are detained in the hotel, until they pay. With Morgan's epiphany of his situation; his deep humiliation by the family's public exposure as social failure, his loneliness in innocence and Pemberton's silence and hesitation, he loses all his dreams: "He had walked from his infancy among difficulties and dangers, but he had never seen a public exposure. Pemberton noticed in a second glance at him that the tears had rushed into his eyes and that they were tears of a new and untasted bitterness." (James: 2014)

This bitterness and disappointment with realizing he is cheated and his being cast off are too much for him. "[h]is sudden bursting into tears as he and his tutor, Pemberton, sit at their lessons is an expression of his mortification over the shabby way the Moreens have used Morgan in their dealings with Pemberton." (Goodman: 1979-80,49) His self-confidence too, is humiliated by the dishonesty and mendacity of both his family and the person he cherishes. Although his tutor, whose sympathy for him is sincere, appreciates him and tries to keep the boy from the family's corruption, contributes to his death; he ignores and neglects his illness and deserts him when he is most needy.

Morgan's death implies not only the corruption of the family and social system to support and sustain such purity but also Pemberton's moral failure: "[B]ringing compassion, comradeship, and vague promises that he cannot fulfill, Pemberton brings a life that is desirable, but not possible...irresponsible and ill-considered affection can do more harm than good." (Eggenschwiler: 1976, 440) So, it is 
obvious that Pemberton has adopted not Morgan but the Moreens' indifference and frailty of conscience. When Morgan loses faith in him, he cannot overcome this psychological tension.

As a narrow-minded Victorian, Mrs. Moreen blames Pemberton in that he has made Morgan study too much. She forgets she has used her own child to get financial and social profit and her relationship with her son was not satisfactory. She does not like to see the facts that he has had not one set of problems; they have given him only anxiety, instability and turmoil and their parenting capacity, responsibility and competence were poor. Since they are needy people, they could accept their situation and focus on love among them instead of pretensions. Morgan's physical absences could be forgiven by him if only his emotional necessities had been met. The family members are not available and sensitive to his needs even when he is hungry for emotional support.

\section{Conclusion}

As a cultural critic, James implies that Victorian values and codes like order, hard work, rationalism, interest in education, and cultivating character and responsibility, though satisfactory in theory, do not work properly due to the subordination to materialistic/classist stance and this is a hindrance to healthy identity formation for children. Childrearing tasks, practices and strategies are on only abstract bases. The hypocritical American Victorianism claims itself as child-focused but proves not. He shows that Victorian culture has neither a clear idea about childhood nor a systematic application of proper education. Instead of practicing these principles, the family becomes a false model to Morgan and ruins him by financial and pretentious worries that the system dictates. James prescribes permanent changes in cultural structures for the future well-being of children and society and draws attention to the lack of child welfare system and educational neglect in both American and European spheres for the setting is both American and European. While portraying a problematical childhood and in the larger sense family tensions, he assigns the tragic outcome to the defective formulation of Victorian family structure.

James is ahead of his time in that he recognizes many home-schooled children are neglected in the social system of American Victorianism; he is also aware of its effects and consequences that neglected children are the unhappy individuals of a society forming neglectful households in the future. The culture victimizes not only children by not achieving their potential - Morgan could be a great man if he was loved, - but also other members of family; they do not behave as they are and they always imitate performing compulsory behaviors. Under these conditions, this culture cannot create stable families and psychologically healthy individuals; always playing, Mrs. Moreen succumbs to a neurotic crisis at the end.

The phenomenon of child neglect keeps its existence even in our time. In the $21^{\text {st }}$ century, proper child-rearing and its individual, familial and social 
dimensions are newly recognized, understood and discussed. James recognizes the importance of parenting and states that the factors that affect parenting traditions and norms must be reviewed. Materialistic drives must not overcome the love parents give to their children for their personal development. Absence of maternal and familial love weakens children's self-esteem and their awareness of being neglected, not loved and wanted humiliates them so much that they may surrender to death. James, as a prescient intellectual, hints the idea of removal of children from neglectful families; if Pemberton could take the responsibility of Morgan, his life would be positively different. While first sharing the children's plight, he calls for orderings in social theory and its right understanding and practice. He advises a psychologically nurturing and supportive environment of child and family together. He counts sustaining factors as physical, emotional and developmental needs among which empathy and compassion come first. These are modern and available ideas in our age, more accurately universal ones.

\section{References}

Canavan, Thomas L. (1973, Summer). The economics of disease in James's 'The Pupil'. Criticism, 15, No.3, 253-264. http://www.jstor.org/stable/23099657 (accessed on 25.12.2014)

Eggenschwiler, David. (1976). James's 'The Pupil': A moral tale without a moral. Studies in Short Fiction, 15, 435-444.

Goodman, Charlotte. (1979-1980, Winter). Henry James, D.H.Lawrence, and the victimized child. Modern Language Studies, 10, no.1, 43-51. http://www.jstor.org/stable/3194621 (accessed on 25.12.2014)

Howe, Daniel Walker. (1975, December). American Victorianism as a culture. American Quarterly, 27, No.5, Special Issue: Victorian Culture in America, 507-532. http://www.jstor.org/stable/2712438 $\quad$ (accessed on 25.12.2014)

James, Henry. "The Pupil". http://www.gutenberg.org (accessed on 03.12.2014)

Kaplan, Sandra J. (2000, Summer). Family violence. New Directions for Mental Health Services, 86, 49-62. doi: 10.1002/yd.23320008607 (accessed on 25.12.2014)

Michals, Teresa. (2011, Summer). Henry James and the invention of adulthood. Novel: A Forum on Fiction, 44, 2, 229-248. doi: 10.1215/002951321260968 (accessed on 01.11.2013) 